\title{
事業所における組織的モビリティ・マネジメントの導入可能性の地域間·業種間比較分析
}

\section{Area Comparative Analysis On Potential To Introduce Organizational Programs Of Mobility Management}

\section{In Workplaces}

谷口綾子**・藤井聡***

Ayako TANIGUCHI** · Satoshi FUJII***

\section{1.はじめに}

言うまでもなく，通勤・業務などの企業活動に関連し た交通行動は，交通計画における重要な要素である. 通 勤による朝夕のラッシュ, 業務目的の移動による(特に尽 間の)交通淽滞など, 地域に大きな影響を及ぼす交通行動 となっている. 交通問題の総合的マネジメントを目指寸 モビリティ・マネジメント(以下 MM と略記)においても, 通勤・通学目的の交通をターゲットとした取組みの重要 性が指摘されており 1)，国土交通省においても，事業所 を対象とした通勤交通マネジメントが施策として進めら れつつある.

事業所におけるモビリティ・マネジメントは二つに大 別される ${ }^{3)}$. 一つは事業所の従業員一人ひとりの行動変 容を促す「個人的プログラム」, もう一つは事業所組織の 変容を促す「組織的プログラム」である. 従業員を対象 とした個人的プログラムはこれまでいくつかの事例が報 告されているが4)59778)，本格的な組織的プログラムは, 我が国においては未だ実施されていないのが現状である.

萩原らは，このような現状を鑑み，事業所における組 織的 MM の実現可能性を, 埼玉県内の事業所へのアンケ 一ト調査により分析している ${ }^{9}$. そして, 多くの事業所 がマイカー通勤抑制組織目標(マイカー通勤を減らした いという意図)を有している一方, 従業員はマイカー通勤 抑制の取組に対して反対していると考えていること，な らびにマイカー通勤抑制組織目標の規定因には「利已的 動機」と「公共的動機」の双方が存在することを明らか にした.

本研究では, 萩原らの提案する組織の行動変容プロセ スの枠組みを用いて，埼玉，三重，大分，磐田，豊田の 各地域の事業所において実施されたアンケート調査結果 を比較分析し, 組織的プログラムの導入プロセスについ ての地域間の共通性がどの様なところにあるのか, そし て，地域間で異なるところはどこか，等を把握すること を通じて, 日本国内の各地域における今後の職場 MM の 展開に資する知見を得ることを目的とする.

*キーワーズ : モビリティ・マネジメント，事業所，地域間比較

** 正員, 工博, 筑波大学大学院システム情報工学研究科 講師 (つくば市天王台 $1-1-1$ )

TEL:029-853-5754, E-mail:taniguchi@risk.tsukuba.ac.jp)

*** 正員, 工博, 東京工業大学大学院理工学研究科 教授

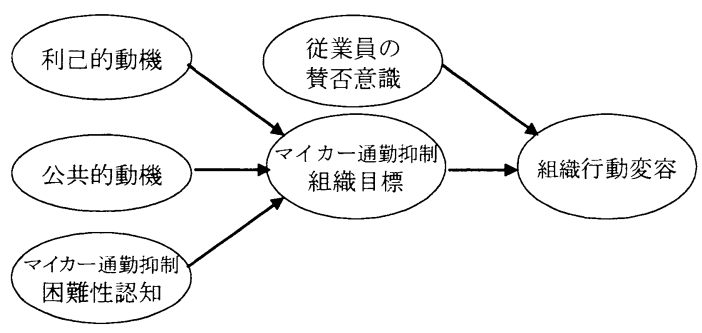

図 1 マイカー通勤抑制の組織行動変容プロセスモデル

\section{2. 組織の行動変容プロセス}

萩原らは, 既往研究 ${ }^{3)}$ における組織的行動の行動変容 プロセスモデルを基本として,「事業所が従業員のマイカ 一通勤を抑制する」という「組織行動変容」について, 図1のようなプロセスモデルを提案している ${ }^{9}$.

このモデルでは, 組織の行動変容が生ずるためには, まずその組織が行動を変容させようと考えること, すな わち「組織目標」が形成されることが不可欠であると仮 定している. そして, その組織目標は, 組織の「利己的動 機」と公共的動機にによって形成されるとともに, 組織が マイカー通勤抑制を困難だと思う程度,「マイカー通勤抑 制困難性認知」の影響を受けることが想定されている.

また,「組織目標」が存在したとしても, それのみで組 織行動変容が起き得るとは限らない.このモデルでは, マイカー通勤抑制に対する従業員の態度をその組織がど のように認知しているか，つまり「従業員の賛否意識」が 組織行動変容に影響すると仮定している. すなわち, 従 業員がマイカー通勤抑制に賛成していると認識している 事業所ほど, 組織行動変容の可能性が高まると想定され ている.

本研究においても, 萩原らの提案した組織的行動の行 動変容プロセスモデルを基本として用いつつ, 地域間比 較分析を行うこととする.

\section{3. 事業所を対象としたアンケート調査概要}

本研究における分析で用いるデー夕は，国土交通省国 土創発調查(通勤交通マネジメントに関する調査研究)と して, 埼玉県, 大分県, 三重県, 磐田市, 豊田市にて平 
成 17 年度に実施された調査によるものである.この調査 は，自動車通勤を抑制に向けた今後の施策展開の基礎資 料収集という行政目的のために，「企業組織」として通勤 交通マネジメントをどのように捉えているかをアンケー トにて問うものであった. 県庁と市という異なる行政レ ベルが混在している理由は, 創発調査が, 自治体レベル を問わない調査であったためである.

アンケート調査のうち, 本研究における分析に用いる 調査項目は表 1 に示すとおりである. ただし, 諸般の事 情から, 三重, 磐田, 豊田の事業所においては企業種別(業 種), 豊田の事業所においては従業員数を問うていない. また, 対象事業所の規模は地域により様々であるが, 配 布・回収方法は郵送配布・郵送回収となっている. その 結果, 埼玉 322 事業所, 三重 8 事業所, 大分 95 事業所, 磐田 14 事業所, 豊田 60 事業所の合計 499 事業所より回 答を得た.

\section{4. 結果}

表 1 の各指標について, 地域別の平均值と標準偏差を 表 2 に，また地域別と業種別(埼玉·大分のみ)の企業規模 (従業員数)を表 3 , 表 4 に示す. さらに, 地域別の業種構 成割合を図 2 に示寸。これらより，三重と磐田では，埼 玉と大分に比べ，大企業が多いこと，また埼玉は建設業 が，大分は「その他」業種が多いと言える. なお，大分 の「その他」の業種には, 旅行代理店, テレビ局, 銀行, カード会社, 生命保険, 病院, 電力会社などの都市型の 事業所が多く含まれている.
表 1 アンケート調査項目

(1) 事業所の概要

・従業員数 (パート・アルバイト含む)

・業種農林水産業・建設業・製告業・運輸業・卸売小売業・公 務・その他)

（2）マイカー通勤抑制に対する組識的意識

・マイカー通勤抑制組織目標：「貴事業所には，マイカー通勤を 滅らしたいといら意図は少しでもあると思いますか?」との 設問に対して，「全く，ないと思う」やや，あると思う」「あ ると思う」「十分, あると思う」の4肢より1つの選択を要請. ・マイカー通勤抑制組織目標の先行要因 : 以下の 6 種類につい て,「マイイカー通勤抑制は・・という意識が…といら設問 に対し，全然ないと思う」から「とても，あると思う」ま での 5 段階で回答を要請.

- 会社のイメージアップにつながる

- 通勤時の交通事故が減る

- 社員の遅刻が減る

- 経費節減 (利益の向上) につながる (以上, 利已的動機)

- 企業の社会的責任の一つである (公共的動機)

一難しい (マイカー通勤抑制困難性認知)

・マイカー通勤印制行動予期 : 「貴事業所で, マイカ一通勤を減 らす試みを実施することは，今後，あり得ると思いますか?」 との設問に対して, 「絶対, あり得ない「やや, あり得る」「あ り得る」「十分, あり得る」の 4 肢より1つの選択を要請.

・公的取り組み協力意向 :『環境対策』『渋滞対策』で自動車通 勤を削減する公的な取り組みがあれば, 協力してもいいと思 いますか?」との設問に対して,「全く, そのように思わない 「少しだけなら, 協力しても良いと思う」「協力しても良いと 思う」「積極的に, 協力したいと思う」の4肢より1つを選択 することを要請.

・従業員の賛否意識：「従業員はマイカー通勤抑制について, ど のように感じていると思いますか?」との設問に対し,「反対 している」から「賛成している」までに5段階で回答を要請.

\begin{tabular}{|c|c|c|c|c|c|c|c|c|c|c|c|c|c|c|c|}
\hline \multirow[b]{2}{*}{ 度数、平均值と標準偏差 } & \multicolumn{3}{|c|}{ 埼焉典 } & \multicolumn{3}{|c|}{ 三重禁 } & \multicolumn{3}{|c|}{ 大分果 } & \multicolumn{3}{|c|}{ 积国 } & \multicolumn{3}{|c|}{ 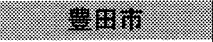 } \\
\hline & 度数 & 平均値 & $\begin{array}{l}\text { 標準 } \\
\text { 偏差 } \\
\end{array}$ & 度数 & 平均値 & $\begin{array}{l}\text { 標準 } \\
\text { 偏差 }\end{array}$ & 度数 & 平均値 & $\begin{array}{l}\text { 標隻 } \\
\text { 偏差 } \\
\end{array}$ & 度数 & 平均値 & $\begin{array}{l}\text { 標隻 } \\
\text { 偏差 }\end{array}$ & 度数 & 平均値 & $\begin{array}{l}\text { 標準 } \\
\text { 偏差 }\end{array}$ \\
\hline 利己的_イメージアップ & 320 & 2.63 & $(1.13)$ & $\overline{8}$ & 3.13 & $\overline{(0.64)}$ & 94 & 2.76 & $(1.19)$ & 13 & 3.23 & (0.83) & $\overline{59}$ & 3.19 & $\overline{(1.01)}$ \\
\hline 利己的_交通事故削減 & 320 & 3.54 & $(1.03)$ & 8 & 3.75 & $(0.71)$ & 95 & 3.40 & $(1.14)$ & 13 & 4.00 & $(0.82)$ & 59 & 3.88 & $(1.04)$ \\
\hline 利已的_遅刻削減 & 319 & 2.30 & $(0.98)$ & 8 & 2.75 & $(0.46)$ & 95 & 2.15 & $(0.89)$ & 13 & 2.31 & $(0.95)$ & 59 & 2.59 & $(1.15)$ \\
\hline 利己的_経費節減 & 320 & 2.58 & $(1.01)$ & 8 & 3.00 & $(0.53)$ & 95 & 2.57 & $(1.09)$ & 13 & 2.85 & $(1.07)$ & 59 & 2.68 & $(1.21)$ \\
\hline 公共的_社会的責任 & 320 & 3.15 & $(0.98)$ & 8 & 3.75 & $(0.46)$ & 95 & 3.20 & $(1.03)$ & 12 & 3.42 & $(0.79)$ & 59 & 3.69 & $(0.91)$ \\
\hline マイカー通勤抑制困難性認知 & 320 & 4.00 & $(0.98)$ & 8 & 4.00 & $(0.53)$ & 94 & 4.00 & $(0.96)$ & 12 & 4.17 & $(0.58)$ & 59 & 3.42 & $(1.22)$ \\
\hline マイカー通勤抑制組織目標 & 313 & 1.98 & $(0.87)$ & 8 & 2.13 & $(0.99)$ & 92 & 2.08 & $(0.87)$ & 13 & 1.92 & $(0.64)$ & 55 & 2.36 & $(0.89)$ \\
\hline マイカー通勤抑制行動予期 & 313 & 1.89 & $(0.77)$ & 8 & 1.88 & $(0.64)$ & 92 & 2.10 & $(0.83)$ & 12 & 1.92 & $(0.51)$ & 55 & 2.18 & $(0.86)$ \\
\hline 従業員の賛否意識 & 314 & 2.33 & $(1.04)$ & 8 & 2.63 & $(1.19)$ & 92 & 2.55 & $\mid$ & 13 & 2.31 & (0.95) & 55 & 2.89 & $(1.13)$ \\
\hline
\end{tabular}

表3 地域別 企業規模(従業員数)

\begin{tabular}{|c|c|c|c|c|c|c|c|c|c|}
\hline & $\begin{array}{l}50 \text { 人 } \\
\text { 未渾 }\end{array}$ & $\begin{array}{l}100 \text { 人 } \\
\text { 未满 }\end{array}$ & $\begin{array}{l}\text { 150人 } \\
\text { 未满 }\end{array}$ & $\begin{array}{c}200 \text { 人满 } \\
\text {. }\end{array}$ & $\begin{array}{l}300 \text { 人 } \\
\text { 未满 }\end{array}$ & $\begin{array}{l}500 \text { 人 } \\
\text { 未满 }\end{array}$ & $\begin{array}{l}1000 \text { 人 } \\
\text { 未渾 }\end{array}$ & 1000人 & 数 \\
\hline $\begin{array}{l}\text { 埼玉 } \\
\end{array}$ & $7.0 \%$ & $9.5 \%$ & $15.8 \%$ & $11.7 \%$ & $16.5 \%$ & $19.9 \%$ & $12.3 \%$ & $7.3 \%$ & 316 \\
\hline 三重 & $0.0 \%$ & $0.0 \%$ & $12.5 \%$ & $12.5 \%$ & $0.0 \%$ & $0.0 \%$ & $12.5 \%$ & $62.5 \%$ & 8 \\
\hline 大分 & $13.2 \%$ & $9.9 \%$ & $29.7 \%$ & $15.4 \%$ & $8.8 \%$ & $15.4 \%$ & $4.4 \%$ & $3.3 \%$ & 91 \\
\hline 磐田 & $0.0 \%$ & $7.7 \%$ & $0.0 \%$ & $15.4 \%$ & $30.8 \%$ & $23.1 \%$ & $0.0 \%$ & $23.1 \%$ & 13 \\
\hline
\end{tabular}

表4 業種別 企業規模(従業員数) 埼玉·大分のみ

\begin{tabular}{|c|c|c|c|c|c|c|c|c|c|}
\hline & $\begin{array}{l}50 \text { 人 } \\
\text { 未満 }\end{array}$ & $\begin{array}{l}\text { 100人 } \\
\text { 未满 }\end{array}$ & $\begin{array}{l}\text { 150人 } \\
\text { 未渾 }\end{array}$ & 200人 & $\begin{array}{l}300 \text { 人 } \\
\text { 未满 }\end{array}$ & $\begin{array}{c}500 \text { 人 } \\
\text { 未满 }\end{array}$ & $\begin{array}{c}1000 \text { 人 } \\
\text { 未满 }\end{array}$ & 1000 & \\
\hline $\begin{array}{l}\text { 設業 } \\
\end{array}$ & $1.0 \%$ & $5.4 \%$ & $13.9 \%$ & $12.4 \%$ & $17.8 \%$ & $26.2 \%$ & $15.8 \%$ & $7.4 \%$ & $\overline{\overline{202}}$ \\
\hline & $9 \%$ & $3.6 \%$ & $23.7 \%$ & 10 & $16.9 \%$ & 18 & $6.8 \%$ & $3.4 \%$ & 59 \\
\hline & $.8 \%$ & $3 \%$ & $18.4 \%$ & $13.2 \%$ & $7.9 \%$ & $15.8 \%$ & $13.2 \%$ & 10.5 & 38 \\
\hline 卸売-小 & $7.6 \%$ & $29.4 \%$ & $26.5 \%$ & $14.7 \%$ & $5.9 \%$ & $2.9 \%$ & 0. & 2.9 & 34 \\
\hline 公矛 & $22.7 \%$ & $9.1 \%$ & $22.7 \%$ & $13.6 \%$ & $13.6 \%$ & $0.0 \%$ & $.0 \%$ & $18.2 \%$ & 22 \\
\hline その他 & $2.2 \%$ & $5.6 \%$ & $27.8 \%$ & $13.9 \%$ & $11.1 \%$ & $13.9 \%$ & $5.6 \%$ & $0.0 \%$ & 36 \\
\hline
\end{tabular}

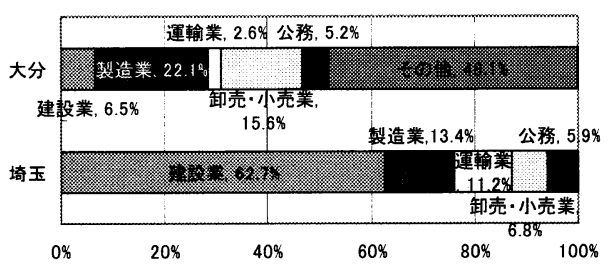

図 2 地域別 業種構成㓶合 
さて, 本研究では, 2 章に述べたマイカー通勤抑制の 組織行動変容プロセスモデルについて, 萩原らの分析と 同様，利己的動機としてイメージアップ，交通事故减， 社員の遅刻減，経費節减，公共的動機として社会的責任 を設定するとともに，本研究では地域ダミー，企業種別 ダミー企業規模(従業員数)が仮説のプロセスモデルにど のように影響しているかを探索的に検討することとした. 地域ダミ一は埼玉, 三重, 大分, 磐田, 豊田のそれぞれ の地域を 1 とし,それ以外の地域を 0 とする変数であり, 企業種別ダミーとは，建設業，製造業，運輸業，卸売小 売業, 公務，その他のそれぞれを 1 とし，それ以外の業 種を 0 とする変数である. アンケート調査票には「農林 水産業」の選択肢を記載したが，本研究で分析対象とし た企業については該当する企業が存在しなかった.

\section{（1）地域ダミーを入れた分析}

本研究ではまず，地域間の差異を明らかにすることを 目的として，全地域のサンプルを用いる一方，地域間の 差異を表現する地域ダミーを導入したモデルを推定した.

モデル推定にあたっては, 複数の重回帰モデルから構 成される階層重回帰モデルの考え方を用いて推定した。 なお，先に述べたとおり，企業種別や従業員数のデータ については，全ての地域で入手できなかったため，本節 では萩原らの提案した基本モデル(図 1 参照)に, 地域ダ ミーのみを挿入したモデル(図3 参照)の分析を行った.

表 5 は，地域ダミーを入れた重回帰分析結果 $(n=478)$ であり, 図4はそれを図示したものである.「マイカー通 勤抑制組織目標」を従属変数とした重回帰分析結果より, マイカー通勤抑制が「イメージアップにつながる」交通 事故减につながる」「経費節減につながる」「企業の社会 的責任である」と考えている企業ほど，マイカー通勤抑 制組織目標が向上するという結果が示された. 一方，マ イカー通勤抑制困難性認知に有意な負の係数が示されて おり，マイカー通勤抑制は難しいと考えている事業所ほ どマイカー通勤抑制組織目標は小さくなることも示唆さ れた. また, 「マイカー通勤抑制行動予期」を従属変数と した重回帰分析結果より，「マイカー通勤抑制組織目標」 「従業員の賛否意識」が，「マイカー通勤抑制行動予期」 に有意な影響を与えていることが分かる。すなおち，マ イカー通勤を減らしたいという意図が強い事業所ほど, そして, 従業員がマイカー通勤抑制に賛成している傾向 が強い事業所ほど，マイカー通勤を減らす試みを実施す ることがあり得ると考えていることが示唆された。 これ らは, 萩原ら ${ }^{9} の$ 分析結果の妥当性を改めて支持するも のと言える.

さらに，「マイカー通勤抑制行動予期」に対して「大分 ダミー」が有意となっていることから，本研究の分析対 象とした事業所のうち，大分の事業所はマイカー通勤を

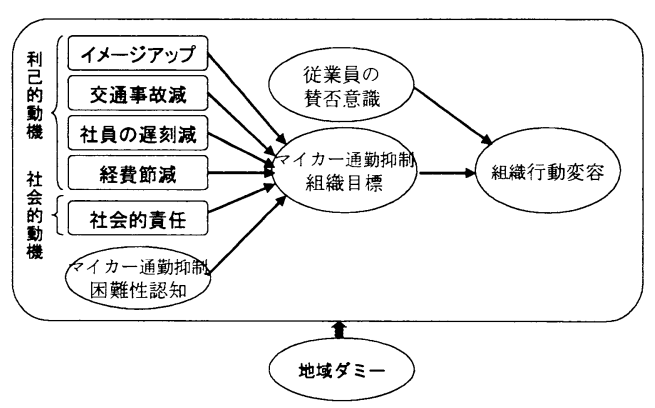

図 3 地域ダミー入り プロセスモデルの因果構造

表 5 階層重回帰分析結果(地域ダミ一入り)

\begin{tabular}{|c|c|c|c|c|c|c|c|}
\hline $\begin{array}{l}\text { 従属 } \\
\text { 変数 }\end{array}$ & & 独立変数 & $\begin{array}{l}\text { ダミー } \\
\text { 変数 }\end{array}$ & $\begin{array}{c}\text { 標準化 } \\
\text { 係数 } \beta\end{array}$ & $t$ & $\begin{array}{l}\text { 有意 } \\
\text { 確率 }\end{array}$ & \\
\hline \multirow{12}{*}{$\begin{array}{c}\text { マ } \\
1 \\
\text { 力 } \\
1 \\
\text { 通 } \\
\text { 勤 } \\
\text { 抑 } \\
\text { 制 } \\
\text { 組 } \\
\text { 織 } \\
\text { 目 } \\
\text { 標 }\end{array}$} & & (定数) & & & 5.50 & 0.00 & ***** \\
\hline & \multirow{4}{*}{ 利已的 } & イメージアップ & & 0.11 & 2.06 & 0.04 & $* *$ \\
\hline & & 交通事故削減 & & 0.11 & 2.24 & 0.03 & $* *$ \\
\hline & & 遅刻削減 & & 0.02 & 0.44 & 0.66 & \\
\hline & & 経費節減 & & 0.12 & 2.51 & 0.01 & $* * *$ \\
\hline & \multicolumn{2}{|c|}{ 公共的 社会的責任 } & & 0.17 & 3.17 & 0.00 & $* * *$ \\
\hline & \multicolumn{2}{|c|}{ マイカ一通勤抑制困難性認知 } & & -0.19 & -4.38 & 0.00 & $* * *$ \\
\hline & \multirow{5}{*}{$\begin{array}{l}\text { ダ 地 } \\
\text { I 域 }\end{array}$} & 埼玉ダミー & - & 0.00 & - & - & \\
\hline & & 三重ダミー & 1 & -0.01 & -0.25 & 0.81 & \\
\hline & & 大分ダミー & 1 & 0.04 & 1.05 & 0.29 & \\
\hline & & 磐田ダミー & 1 & -0.04 & -0.94 & 0.35 & \\
\hline & & 豊田ダミ一 & 1 & 0.04 & 0.89 & 0.37 & \\
\hline \multirow{8}{*}{$\begin{array}{l}\text { 抑マ } \\
\text { 制イ } \\
\text { 行力 } \\
\text { 動 I } \\
\text { 矛通 } \\
\text { 期勤 }\end{array}$} & \multirow{2}{*}{\multicolumn{2}{|c|}{$\begin{array}{c}\quad \text { (定数) } \\
\text { マイカ一通勤抑制組織目標 }\end{array}$}} & & & 5.69 & 0.00 & *** \\
\hline & & & & 0.77 & 25.95 & 0.00 & $* * *$ \\
\hline & \multicolumn{2}{|c|}{ 従業員の賛否意識 } & & 0.08 & 2.67 & 0.01 & *** \\
\hline & \multirow{5}{*}{$\begin{array}{l}\text { ダ 地 } \\
\vdots\end{array}$} & 埼玉ダミー & - & 0.00 & - & - & \\
\hline & & 三重ダミー & 1 & -0.02 & -0.80 & 0.42 & \\
\hline & & 大分ダミー & 1 & 0.07 & 2.31 & 0.02 & $* * *$ \\
\hline & & 磐田ダミー & 1 & 0.01 & 0.52 & 0.60 & \\
\hline & & 豊田ダミー & 1 & 0.00 & -0.15 & 0.88 & \\
\hline
\end{tabular}

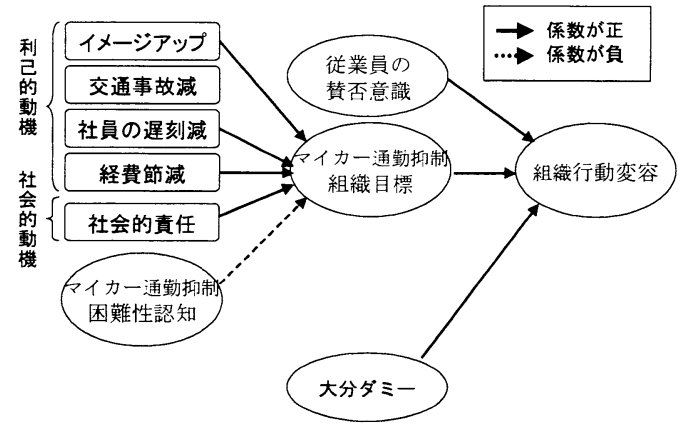

困 4 地域ダミーをいれた階層重回帰分析結果

減らす試みを実施することがあり得ると考えている傾向 が, 埼玉県よりも強いということが示唆された.ただし， それ以外の地域ダミーはいずれも有意な水準には届かな かった.このことは，大分県においては上述のような傾 向が見られる一方，それ以外の地域における地域間の従 属変数の差異は，少なくとも今回の分析においては見ら れず，組織の行動変容プロセスは，今回の分析に用いた 説明変数によっておおよそ説明可能であることを意味す るものと考えられる. なお，大分ダミ一のみが有意とな った理由は定かではないが，少なくとも埼玉と比較する 


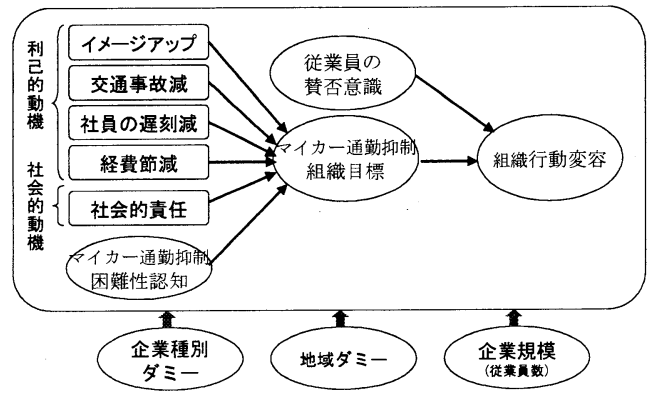

図 5 企業種別・地域ダミーと従業員数をいれ た組織行動変容プロセスモデルの因果構造

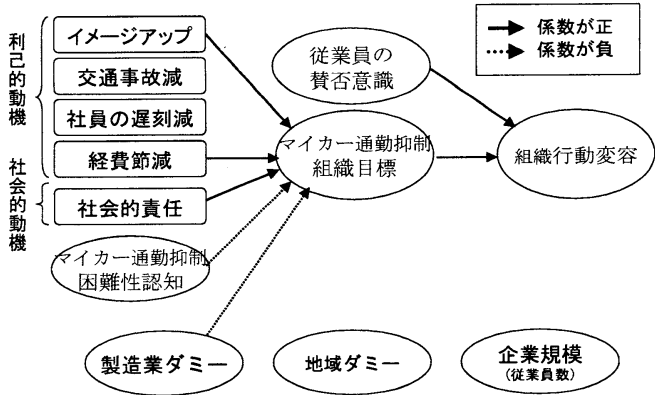

図6 企業種別・地域ダミーと従業員数をいれた 階層重回帰分析結果

と(図2), 公共交通など他手段に転換しやすい都市型 のサービス業が多いことが影響している可能性も考 えられる.

\section{（2）企業規模と企業種別に関する分析 (埼玉 ・ 大分)}

(1)プロセスモデルの検証

以上の分析では，得られたデータすべてを用いた分析 を行ったが，埼玉県と大分県においては，企業規模と企 業種別のデータも得られていることから，これら二地域 から得られたデー夕を用いて，企業規模と企業種別が及 ぼす影響に関する分析 $(\mathrm{n}=378)$ を行った. 図 5 は，埼玉 と大分の事業所における企業種別と従業員数を加味した 組織行動変容モデルの因果構造であり，このモデルを階 層重回帰分析により分析した結果を表 6, 図 6 に示す.

先の分析において有意であった係数は，一部の例外を 除くと基本的に今回の分析でも有意であり，また，先の 分析で有意でなかった係数は今回も有意ではなかった. 以下では，その一部の例外に関する考察，ならびに，今 回改めて導入した変数の効果に関する考察をおこなう.

まず，交通事故削減についての期待が抑制組織目標に 対して有意ではなくなっている.この結果は, 三重, 磐 田，豊田において，大分や埼玉よりも相対的に交通事故 削減についての期待の重要性が高いという可能性を示す ものと考えられる. なお, 表2より, 大分と埼玉では「マ イカー通勤抑制が交通事故削減につながる」という意識 が相対的に低い傾向が示されているが，このことが上記 結果に関連している可能性も考えられる. 一方, 大分ダ
表 6 階層重回帰分析結果(従業員数 - 企業種別入り, 埼玉 - 大分)

\begin{tabular}{|c|c|c|c|c|c|c|c|}
\hline $\begin{array}{l}\text { 従属 } \\
\text { 変数 }\end{array}$ & & 独立変数 & 怨- & $\begin{array}{l}\text { 標準化 } \\
\text { 係数 } \beta\end{array}$ & $\mathrm{t}$ & $\begin{array}{l}\text { 有意 } \\
\text { 確率 }\end{array}$ & \\
\hline \multirow{16}{*}{$\begin{array}{l}\text { ₹ } \\
1 \\
\text { 力 } \\
1 \\
\text { 通 } \\
\text { 勤 } \\
\text { 抑 } \\
\text { 制 } \\
\text { 組 } \\
\text { 織 } \\
\text { 目 } \\
\text { 標 }\end{array}$} & & (定数) & & & 4.90 & 0.00 & *** \\
\hline & \multirow{4}{*}{ 利已的 } & イメージアップ & & $\overline{0.16}$ & 2.66 & $\overline{0.01}$ & *** \\
\hline & & 交通事故削減 & & 0.05 & 0.85 & 0.40 & \\
\hline & & 遅刻削減 & & 0.00 & 0.07 & 0.95 & \\
\hline & & 経費節減 & & 0.12 & 2.07 & 0.04 & $* *$ \\
\hline & \multicolumn{2}{|c|}{ 公共的 社会的責任 } & & 0.17 & 2.75 & 0.01 & *** \\
\hline & \multicolumn{2}{|c|}{ マイカー通勤抑制困難性認矢 } & & -0.14 & -2.87 & 0.00 & $* * *$ \\
\hline & \multicolumn{2}{|c|}{ 従業員数 } & & 0.02 & 0.38 & 0.70 & \\
\hline & 地域 & 埼玉ダミー & - & 0.00 & - & - & \\
\hline & \multirow[t]{2}{*}{ ダミー } & 大分ダミ一 & 1 & 0.03 & 0.48 & 0.63 & \\
\hline & & 建設業 & - & 0.00 & - & - & \\
\hline & \multirow{5}{*}{$\begin{array}{l}\text { 名企 } \\
\text { 業 } \\
\text { 種 } \\
\text { 別 }\end{array}$} & 製造業 & 1 & -0.10 & -2.00 & 0.05 & $*$ \\
\hline & & 運輸業 & 1 & 0.05 & 0.98 & 0.33 & \\
\hline & & 卸売、小売業 & 1 & -0.05 & -1.06 & 0.29 & \\
\hline & & 公務 & 1 & -0.07 & -1.50 & 0.13 & \\
\hline & & その他 & 1 & 0.00 & 0.07 & 0.95 & \\
\hline & & (定数) & & & 4.71 & 0.00 & $* * *$ \\
\hline & \multirow{2}{*}{\multicolumn{3}{|c|}{$\begin{array}{l}\text { マイカー通勤抑制組織目標 } \\
\text { 嗞對亘否音識 }\end{array}$}} & 0.76 & 22.57 & 0.00 & *** \\
\hline \multirow{2}{*}{$\begin{array}{l}1 \\
\text { 力 } \\
\text { I }\end{array}$} & 従業員 & & & 0.06 & 1.91 & 0.06 & $*$ \\
\hline & \multicolumn{2}{|c|}{ 従業員数 } & & 0.01 & 0.29 & 0.77 & \\
\hline \multirow{8}{*}{$\begin{array}{l}\text { 通 } \\
\text { 勤 } \\
\text { 抑 } \\
\text { 制 } \\
\text { 行 } \\
\text { 動 } \\
\text { 予 } \\
\text { 期 }\end{array}$} & \multirow{2}{*}{$\begin{array}{l}\text { 地域 } \\
\text { 名 } \\
\end{array}$} & 埼玉ダミー & - & 0.00 & - & - & \\
\hline & & 大分ダミー & 1 & 0.06 & 1.22 & 0.22 & \\
\hline & \multirow{6}{*}{$\begin{array}{l}\text { ダ企 } \\
\text { 業 } \\
\text { 種 } \\
\text { 別 }\end{array}$} & 建設業 & - & 0.00 & - & - & \\
\hline & & 製造業 & 1 & 0.01 & 0.19 & 0.85 & \\
\hline & & 運輸業 & 1 & 0.03 & 0.81 & 0.42 & \\
\hline & & 卸売、小売業 & 1 & 0.00 & -0.04 & 0.97 & \\
\hline & & 公務 & 1 & -0.01 & -0.44 & 0.66 & \\
\hline & & その他 & 1 & 0.03 & 0.56 & 0.58 & \\
\hline
\end{tabular}

ミーが有意でなくなっているが，これは，大分における 抑制行動意図が埼玉県に比べて高かったのは企業の業種 の分布の違いによってもたらされていたという可能性を 示唆している. 実際, 図 2 の結果より, 埼玉と大分の業 種は大きく異なっていることが示されている.

次に，従業員数については有意な影響が見られなかっ た. また, 業種については, 「マイカー通勤抑制組織目標」 に対して「製造業ダミー」がマイナスに有意な傾向を示 していることとなった. このことから，本研究の分析対 象とした事業所のうち，業種が製造業である事業所はマ イカー通勤を減らしたいという意図が低い可能性が示唆 された。

(2)イカー通勤抑制組織目標・行動予期の先行要因に関 する分析

ここでさらに, 今回の分析で導入した従業員数や業種, ならびに，地域ダミーが企業属性，抑制組織目標の先行 要因に及ぼす影響を把握するため, 7 つの先行要因を従 属変数とした重回帰分析を行った結果を表 7 に示す.

表 7 より，従業員数が多いほど，マイカー通勤抑制に より「従業員の遅刻が減る「経費が節減できる」と考え， 「マイカー通勤抑制は困難ではないと考える傾向が示唆 されたが，これらの結果は，従業員の多、企業ほど，職 場 $\mathrm{MM}$ の実施・参加を促す動機をより強く持っているこ とを示している.このことは, 職場 MM を実施する際に, 
表 7 組織目標·行動予期の先行要因における重回帰分析結果

\begin{tabular}{|c|c|c|c|c|c|c|c|c|c|c|c|c|c|}
\hline \multirow[t]{2}{*}{ 従属変数 } & \multirow[b]{2}{*}{ 多ミー } & \multicolumn{3}{|c|}{ 従業員の賛否意識 } & \multicolumn{3}{|c|}{ 利己的_イメージアッ } & \multicolumn{3}{|c|}{ 利已的_交通事故削派 } & \multicolumn{3}{|c|}{ 利己的_遅刻削減 } \\
\hline & & $\beta$ & $\mathrm{t}$ & $\mathrm{p}$ & $\beta$ & $t$ & $\mathrm{p}$ & $\beta$ & $\mathrm{t}$ & $\mathrm{p}$ & $\beta$ & $\mathrm{t}$ & $\mathrm{p}$ \\
\hline 数) & & & 28.15 & 0.00 & & 29.73 & 0.00 & & 40.74 & 0.00 & & 28.92 & 0.00 \\
\hline 業員 & & 0.03 & 0.57 & 0.57 & .08 & 1.65 & 0.10 & 0.06 & 1.22 & 0.22 & 0.11 & 2.16 & 0.03 \\
\hline 種_ & - & & - & - & & & 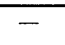 & 00 & - & - & 00 & - & - \\
\hline 種_ & 1 & -0.08 & -1.3 & 0.17 & .20 & -3. & 0.00 & -0.06 & -1.05 & 29 & -0.07 & -1.17 & 0.2 \\
\hline 種_ & 1 & 0.19 & 3. & 0. & -0.12 & -2.34 & 0.02 & 0.12 & 2.21 & 0.03 & 0.04 & 0.74 & 0.46 \\
\hline 種_Â & 1 & -0.07 & -1.19 & 0.24 & -0.01 & -0.15 & 0. & 0.01 & 0.19 & 0.85 & 0.02 & 0.38 & 0.70 \\
\hline 鞂 & 1 & -0.05 & -0.95 & 0.34 & -0.01 & -0.15 & 0. & 0.05 & 0.95 & 0. & 0.08 & 1.64 & 0.10 \\
\hline & 1 & 0.04 & 0.50 & 0.62 & -0.13 & -1.76 & 0.0 & 0.01 & 0.16 & 0.88 & 0.08 & 1.04 & 0.30 \\
\hline & - & & - & 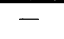 & & & & & 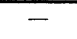 & & 00 & - & - \\
\hline & & .08 & & & & & & & & & & & \\
\hline
\end{tabular}

$\beta:$ 標準化係数, $\mathrm{t}: \mathrm{t}$ 值， $\mathrm{p}$ : 有意確率(両側)

\begin{tabular}{|c|c|c|c|c|c|c|c|c|c|c|}
\hline \multirow[t]{2}{*}{ 従属変数 } & \multirow[b]{2}{*}{$\begin{array}{l}\text { ダミー } \\
\text { 変数 }\end{array}$} & \multicolumn{3}{|c|}{ 利己的_経費節減 } & \multicolumn{3}{|c|}{ |公共的_社会的責任 } & \multicolumn{3}{|c|}{ |マイカー通勤版制困難性認知 } \\
\hline & & $\beta$ & $\mathrm{t}$ & $\mathrm{p}$ & $\beta$ & $\mathrm{t}$ & $\mathrm{p}$ & $\beta$ & $\mathrm{t}$ & $\mathrm{p}$ \\
\hline$\overline{\text { (定数) }}$ & & & $\overline{\overline{30.54}}$ & $\overline{0.00}$ & & 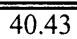 & $\overline{0.00}$ & & $\overline{52.98}$ & $\overline{0.00}$ \\
\hline 従業員数 & & 0.10 & 1.89 & 0.06 & 0.08 & 1.61 & 0.11 & -0.10 & -1.91 & 0.06 \\
\hline 業種 建設ダミー & $\overline{-}$ & 0.00 & - & - & 0.00 & - & - & 0.00 & - & - \\
\hline 業種_製造ダミー & 1 & -0.08 & -1.51 & 0.13 & -0.22 & -3.93 & 0.00 & 0.06 & 1.13 & 0.26 \\
\hline 業種_運輸ダミー & 1 & 0.03 & 0.60 & 0.55 & 0.03 & 0.55 & 0.58 & -0.13 & -2.54 & 0.01 \\
\hline 業種_卸小売ダミー & 1 & 0.05 & 0.98 & 0.33 & 0.00 & 0.07 & 0.95 & -0.02 & -0.41 & 0.68 \\
\hline 業種_公務ダミー & 1 & 0.01 & 0.24 & 0.81 & -0.06 & -1.13 & 0.26 & -0.03 & -0.49 & 0.63 \\
\hline 業種 その他ダミー & 1 & -0.03 & -0.46 & 0.64 & -0.11 & -1.49 & 0.14 & -0.03 & -0.41 & 0.68 \\
\hline 埼玉ダミー & $\overline{-}$ & 0.00 & - & - & 0.00 & - & - & 0.00 & - & - \\
\hline 大分ダミー & 1 & 0.03 & 0.40 & 0.69 & 0.09 & 1.23 & 0.22 & 0.04 & 0.51 & 0.61 \\
\hline
\end{tabular}

大企業を対象とした戦略を検討することの妥当性を示唆 するものと考えられる.

また，企業種別が「運輸業」の事業所は，マイカー通勤 抑制は，「イメージアップにはつながらないと考えてい るものの,「従業員は賛成している」「交通事故削減につな がる」と考えており,「マイカー通勤抑制は困難ではない と考えている傾向が示唆された. このこともまた，職場 MMに運輸業の企業が積極的に参与する潜在的可能性が 存在することを示唆している. この理由は定かではない が，運輸業には，公共交通事業者や宅配便などが含まれ ており，交通関連施策には比較的敏感であることが想像 されるほか，交通事故などを強く忌避する傾向が考えら れることから, 職場 MM に肯定的態度を形成している可 能性が考えられる.

さらに,「製造業」の事業所は, マイカー通勤抑制に「イ メージアップにはつながらない「企業の社会的責任の一 つではないとの意識を持っている傾向が示唆された.こ のことと，図6に示した階層重回帰分析結果において, 製造業ダミーがマイナスに有意傾向にあったことを考え 合わせると，製造業は，概して職場 MM に否定的な態度 を形成しがちである可能性をするものと考えられる。こ の理由は定かではないが，製造業は一般に公共交通など マイカーの代替手段が不便な地域に立地することが多い ことに起因している可能性も考えられる.
最後に，大分ダミーについては，マイカー通勤抑制は 「遅刻の減少にはつながらないと考えている傾向が示唆 された．これは，表2で大分の「遅刻に関する指標が相 対的に低いこととも関連する結果であるとも考えられる.

\section{5. おわりに}

本研究では, 先行研究9 における事業所モビリティ・マ ネジメントの導入可能性に関する分析結果が, 他の地域 の事業所においても同様の傾向を示寸のか否か，またど のような属性の事業所において組織的プログラムの導入 可能性があるのかを検証するため, 萩原らの提案する組 織の行動変容プロセスの枠組みを用いて, 埼玉, 三重, 大分, 磐田, 豊田の各地域の事業所において実施された アンケート調查結果の分析を行った，その結果，萩原ら の提案したマイカー通勤抑制の組織行動変容プロセスモ デルが，他の地域の事業所においても成立することが示 唆された. 特に, 従業員数や, 企業の種別を加味したモ デルを推定したところ, 組織的プログラムに対する企業 意識の地域間の差異は, 有意なものではなくなった，と いう結果が示された.この結果は, 職場MMへの各企業 の参加意思決定プロセスは地域間でおおよそ共通してお り，大きな本質的な地域間差異は存在していない可能性 を示唆寸るものである. このことは, 職場 MMにおける 
組織的プログラムのおおようの構成は, 日本国内の広範 な地域で共有可能であることを示唆するものである.

一方, 従業員数が多い事業所, ならびに, 運輸業の事 業所においては, 職場 MM を肯定的にとらえる潜在的可 能性が示唆された. その一方で, 製造業は, 職場 MMに 対して否定的にとらえる潜在的可能性が存在することが 示された. こうした知見は, 当該地域の職場 $M M$ 展開 するにあたって，まずはどういった企業から接触を図っ ていくことが得策であるかを考える上で，有益な基礎情 報となりうる可能性があるものと考えられる.もちろん， このことは, 現在マイカー利用削減の強い動機を持って いない事業所をそのまま放置してよいということを意味 しているわけではない. しかしながら, 事業所 MM を広 範に進めるに当たり, まずは動機の強い事業所を対象と し，事例を積み重ねることは一定の妥当性があると考え られる. 実際, 行政担当者の報告によると，ある都市の $\mathrm{A}$ 銀行に通勤 MM 推進を依頼したところ, 「近所の B 銀 行が実施しているなら,やりましょう」という反応だった そうである. 事業所 MM を導入している他社を見ること で，自社に導入しようと考える企業も存在する可能性が あるのである、この意味で，まずは実施しや寸い事業所 を優先することには,一定の妥当性があると考えられる.

今後は, 効果的な事業所モビリティ・マネジメントを進 めていくため, 本研究における分析を, さらに様々な地 域·業種において重ねていく必要がある.
土創発調査において収集したものである.ご提供いただい た関係各位にここに記して謝意を表す。

《参考文献>

1) 土木学会 : モビリティ・マネジメントの手引き : 公共交通と クルマのかしこい使い方を考えるための交通施策, 土木学会, 2005.

2）国土交通省「通勤交通マネジメント」HP : http:/www.mlit.go.jp/kokudokeikaku/souhatu/h17seika/1tuukin/1tuu kin.html

3) 藤井聡, 谷口綾子 : 職場モビリティ・マネジメントの現状と 課題:「個人的プログラム」を含めた「組織的プログラム」 の本格的展開に向けて, 土木計画学研究・講演集 (CDROM), vol.32, 2005.

4) 谷口綾子, 藤井聡 : 職場における通勤行動を対象とした MM の効果分析一山陽電鉄沿線企業への働きかけ一, 土木計画学 研究・講演集(CD-ROM) Vol.32,2005.

5) 萩原剛, 村尾俊道, 島田和幸, 義浦慶子, 藤井聡 : 大規模職 場 MM の集計的効果検証と MM 施策効果の比較分析, 土木学 会論文集，(投稿中).

6) 橋本康成, 谷亨, 高山純一, 出口正: コーディネーター方式 によるエコ交通運動の取り組み, 土木計画学研究・講演集 (CD-ROM), vol.26, 2002.

7) 大藤武彦，松村暢彦，大西孝二: 事業所を対象とした自律的 交通マネジメントプログラム実践の試み，士木計画学研究・ 講演集 (CD-ROM), vol.29, 2004.

8）松村暢彦：マイカー通勤削減を目的とした通勤手当に対する 通勤者の意識と行動に関する研究，都市計画論文集， 37,pp.259-264, 2002.

9) 萩原剛, 藤井聡 : 事業所における組織的なモビリティ・マネジ メントに関する分析，土木学会論文集，(投稿中).

謝辞 : 本研究で報告したデータは, 国土交通省の平成 17 年度国

事業所における組織的モビリティ・マネジメントの導入可能性の地域間・業種間比較分析* 谷口綾子 $* * \cdot$ 藤井聡 $* * *$

本研究では，萩原らの先行研究における事業所モビリティ・マネジメントの導入可能性に関する分 析結果が, 他地域でも同様の傾向を示すのか, またどのような属性の事業所で組織的プログラムの導 入可能性があるのかを検証するため, 埼玉, 三重, 大分, 磐田, 豊田の各地域の事業所で実施された アンケート調查結果の分析を行った. その結果, 萩原らの提案したマイカー通勤抑制の組織行動変容 プロセスモデルが, 他地域の事業所においても成立することが示唆された. また従業員数が多い事業 所, 運輸業においては, 職場MMを肯定的にとらえる可能性が示唆された一方で, 製造業は職場 MM に対して否定的にとらえる可能性が存在することが示された.

\section{Area Comparative Analysis On Potential To Introduce Organizational Programs Of Mo bility Management In Workplaces*}

By Ayako TANIGUCHI** • Satoshi FUJII***

In this paper, in order to test a potential to introduce organizational program for workplace mobility management (MM), we retake a test the organizational attitude and behavior modification model based on the frame of analysis by Hagihara et.al. using the questionnaire survey in workplaces. We analyzed the questionnaire data for the sake of comparison implemented in five areas, Saitama, Mie, Ooita, Iwata, Toyota, and comparison by categories of business and employee numbers. In the result, the organizational model suggested by Hagihara et.al, was supported in the both five areas. The result also indicates companies which employ a lot of person and transport companies were most likely to recognize MM as positive, however, manufacturing business were likely to recognize as negative. 